\title{
Significant differences in FcyRIla, FcyRIIla and FcyRIIlb genes polymorphism and anti-malarial IgG subclass pattern are associated with severe Plasmodium falciparum malaria in Saudi children
}

\author{
Amre Nasr ${ }^{1,2^{*}}$ (D) Ahmad Aljada ${ }^{3}$, Osama Hamid ${ }^{4}$, Hatim A. Elsheikh ${ }^{5}$, Emad Masuadi ${ }^{2,6}$, Ahmad Al-Bawab ${ }^{1}$, \\ Themer H. Alenazi ${ }^{7,8}$, Amir Abushouk ${ }^{9,10}$ and Ayman M. Salah ${ }^{10,11}$
}

\begin{abstract}
Background: The FcyRs genotypes have been reported to play a key role in the defence against malaria parasites through both cellular and humoral immunity. This study aimed to investigate the possible correlation between FcyR (IIa, IIIa, and IIIb) genes polymorphism and the clinical outcome for anti-malarial antibody response of Plasmodium falciparum infection among Saudi children.

Methods: A total of 600 volunteers were enrolled in this study, including 200 malaria-free control (MFC) subjects, 218 patients with uncomplicated malaria (UM) and 182 patients with severe malaria (SM). The FCYR genotypes were analysed using PCR amplification methods, and measurements of immunoglobulin were determined using enzymelinked immunosorbent assay (ELISA) technique.

Results: The data revealed that the FCYRlla-R/R131 showed a statistically significant association with SM patients when compared to UM patients. Furthermore, higher levels of lgG1, lgG2, and lgG4 were associated with the FCYRIla-H/H131 genotype among UM patients. Although the FCYRIIa-FN176 genotype was not associated with UM, it showed a significant association with severe malaria. Interestingly, the FCYRIIIa-VN176 genotype offered protection against SM. Moreover, SM patients carrying the FCYRIIIa-F/F genotype showed higher levels of AMA-1-specific IgG2 and IgG4 antibodies. The FCYRIIIb-NA1/NA1 and FCyRIIIb-NA2/NA2 genotypes did not show significant differences between the UM and the MFC groups. However, the genotype FCYRIIIb-NA2/NA2 was statistically significantly associated with SM patients.

Conclusions: The data presented in this study suggest that the influence of the FCYRIla-R/R131, FCyRIIIa-F/F176 and FCYRIIIL-NA2/NA2 genotypes are statistically significantly associated with SM patients. However, the FCYRIla-H/H13 and FCYRIIIa-VN176 genotypes have demonstrated a protective effect against SM when compared to UM patients. The impact of the FcyR (Ila, IIla and IIIb) gene variants and anti-malaria IgG subclasses play an important role in susceptibility to malaria infection and disease outcome in Saudi children.
\end{abstract}

Keywords: Plasmodium, Falciparum, Malaria, IgG subclass, AMA-1, Saudi, Children

\footnotetext{
*Correspondence: nasra@ksau-hs.edu.sa

1 Department of Basic Medical Sciences, College of Medicine, King Saud Bin Abdulaziz University for Health Sciences (KSAU-HS), Riyadh, Kingdom of Saudi Arabia

Full list of author information is available at the end of the article
}

\section{Background}

Malaria is a parasitic infectious disease caused by five species of Plasmodium that are transmitted to humans via mosquito bites. Of these species, Plasmodium 
falciparum, which is most prevalent in Africa, and Plasmodium vivax pose the greatest threat to health. In Saudi Arabia, P. falciparum represents about 99\% of the total cases of malaria, while only $1 \%$ of patients are infected by $P$. vivax. In 2019, malaria affected about 229 million worldwide and contributed to 409,000 deaths. Children below the age of five were amongst the most vulnerable groups affected by the disease [1]. According to the WHO figures, between 2010-2015 in Saudi Arabia, the number of recorded malaria patients was steadily below 100 , but it rose to 272 cases in 2016 . This was mostly due to increased migration of people from war zones along the border with Yemen, as well as difficulties in providing adequate medical services in those regions. However, the health service in this country remains vigilant and offers free diagnosis and treatment for all patients.

Given the increase in the number of malaria infections and its apparent threat to people's lives; there was a call for further studies that can assess individual's susceptibility. This led to the current study in which the authors looked at genes $(\mathrm{Fc} \gamma \mathrm{R})$ within the innate immunity that are responsible for receptor expression on immune cells (including macrophages, neutrophils, NK cells). These cell receptors have the ability to recognize certain antibodies that will bind to antigens, such as antigens of $P$. falciparum.

There are three sub-families of surface receptors for the Fc region of the IgG, designated as FcyRI, II, and III [2]. Most immune cells express Fc receptors that are crucial for determining the specificity of IgG antibodies [3]. Fc $\gamma \mathrm{R}$ induces monocyte activation features such as phagocytosis, degranulation, superoxide generation, antibody-dependent cell inhibition, cytokine production, and antibody regulation, which are essential for host defence and immune regulation $[4,5]$. The effectiveness of IgGinduced $\mathrm{F} c \gamma \mathrm{R}$ activity demonstrates inter-individual heterogeneity due to the genetic polymorphisms of the three subclasses of FcyR; FcyRIIa (CD32a), FcyRIIIa (CD16a), and FcyRIIIb (CD16b) [5].

Previous studies showed that several polymorphisms have been detected in the $\mathrm{Fc} \gamma$ genes encoding these receptors $(\mathrm{Fc} \gamma \mathrm{Rs})$, associated with susceptibility or resistance to malaria outcome in different populations $[3,4$, 6-12]. A recent review by Amiah et al. [13] described the Fc $\gamma$ Rs polymorphisms and the impact of these variations on the response of the host to infection. It also provided new perspectives for the potential design of an effective malaria vaccine [13].

The present study aimed to investigate the possible relationship between the expression of FcyRIIa (CD32a), FcyRIIIa (CD16a), and FcyRIIIb (CD16b) gene variants and the antibodies against the malarial apical membrane antigen 1 (AMA-1) in association with the susceptibility to malaria infection among Saudi children.

\section{Methods \\ Study area}

This study was conducted at Bani Malik General Hospital in Jazan Region (BMGHJ), located in the Southern part of the Kingdom of Saudi Arabia (KSA), during three transmission seasons from October 2015 to March 2018. The highlights of this study setting have already been described in related previous studies [3, 14-16].

\section{Study design and patients}

A prospective case-control study was conducted in children attending the outpatient clinic of BMGHJ, with a confirmed clinically diagnosed $P$. falciparum infection. Patients with positive thick blood film for $P$. falciparum asexual parasites were recruited based on the microscopic diagnosis.

Participants with no features of severe malaria were defined as having uncomplicated $P$. falciparum infection. Children were diagnosed with severe malaria on the basis of one or more of the following: severe malarial anaemia, cerebral malaria, hypoglycaemia, jaundice, acidosis, acute kidney injury (renal impairment), significant bleeding, pulmonary oedema, and shock as described in detailed by the World Health Organization (WHO) [17]. These clinical manifestations occurred in the absence of any identifiable alternative cause other than P. falciparum asexual parasitaemia. Children with cerebral malaria had a Blantyre Coma Score $(\mathrm{BCS})<3$ at $4 \mathrm{~h}$ post-admission. Children with severe malarial anaemia had a blood haemoglobin concentration of ${ }^{<} 5 \mathrm{~g} / \mathrm{dL}$ or a haematocrit value of $<15 \%$ together with a parasite count above $10,000 / \mu \mathrm{L}$. All other children recruited in the study had a haemoglobin concentration above this level. The control group were selected from the Child and Woman Health Clinics (CWHC) that provide children health services including routine vaccinations, as well as providing seasonal vaccines for children. Once the sample was collected, it was matched for age, gender, and ethnicity. Enrolment to the control group was confirmed following a physical clinical examination to ensure that the children did not have serious illnesses or any signs/symptoms of malaria according to information provided by parents/guardians.

The study excluded children with multiple severe malaria complications or any co-infectious diseases. None of the participants were positive for HIV. All the children were recruited during three malaria transmission seasons from October 2015 to March 2018. 


\section{Sample collection}

After the diagnosis of malaria and before the start of the pharmacological course of treatment; $100 \mu \mathrm{L}$ of blood was spotted and dried on filter paper (Qualitative filter paper, Grade 1, circles, diam. $42.5 \mathrm{~mm}$ from Whatman ${ }^{\circledR}$, Sigma-Aldrich ${ }^{\circledR}$ ). This collected sample was used for investigating $\mathrm{Fc} \gamma$ receptor gene polymorphism, parasite detection using PCR, and measurement of immunoglobulins as described earlier [18, 19].

\section{Serum elution from filter-paper samples}

To elute dried samples from filter-paper, a hole puncher of $\phi 6 \mathrm{~mm}$ was used for punching out filter-paper discs and placed in Eppendorf tubes with $100 \mu \mathrm{L}$ of phosphate-buffered saline (PBS). Subsequently, the discs were transferred onto $10 \mathrm{~mL}$ tubes. Then, 500 $\mu \mathrm{L}$ of (PBS) with $0.05 \%$ Tween and $0.5 \%$ bovine serum albumin (BSA) were added to the tubes and incubated under shaking for $2 \mathrm{~h}$ at room temperature. After incubation, the samples were vigorously shaken with a vortex for $30 \mathrm{~s}$, and the supernatants containing the eluted sera were aliquoted in cryotubes $(1.5 \mathrm{ml})$ and stored at $-20{ }^{\circ} \mathrm{C}$ till analysis. Each extracted sample contained an approximately 1:100 diluted serum [18].

\section{DNA extraction}

DNA was extracted from $50 \mu \mathrm{L}$ dried drop of blood sample on the filter paper using the QIAamp DNA Mini Kit (Qiagen ${ }^{\circledR}$, Hamburg, Germany). The extracted DNA was re-suspended in a $150 \mu \mathrm{L}$ of Tris-borateEDTA (TBE) buffer.

\section{Parasite genotype}

Detection of $P$. falciparum was based on targeting the $A M A-1 \_3 D 7$ gene using polymerase chain reaction (PCR) from $5 \mu \mathrm{L}$ of the extracted DNA samples [20].

\section{Enzyme-linked immunosorbent assays (ELISA)}

IgG subclass antibodies were measured against the recombinant AMA-1 anti-malarial antigen. The total levels of IgG and its subclasses were measured using enzyme-linked immunosorbent assays (ELISA) as previously described in detail $[11,21]$, and as recently reported [22].

\section{Genotyping of FcyRs polymorphisms}

The FcyRIIa-131R/H (rs1801274, assay ID: C__9077561_20) and FcyRIIIa-176F/V (rs396991, assay ID: C__25815666_10) polymorphisms were genotyped using the high-throughput TaqMan ${ }^{\circledR} 5^{\prime}$ allelic discrimination assay-by-design method, as per the instructions of the manufacturer (Applied Biosystems, Foster City,
CA, USA). The Fc RIIIIb-NA1/NA2 genotyping for the rs448740 (N65S) and rs147574249 (N82D) was carried out in accordance with the formerly described Restriction Fragment Length Polymorphism (RFLP) method $[12,23]$.

\section{Statistical analysis}

Statistical analysis was done by SPSS statistical software version 23 for Windows (IBM@ SPSS $^{\odot}$ statistics). In this study, the median and $25 \%$ and $75 \%$ quartile of antibody (total IgG and IgG subclasses) levels were analysed using nonparametric (Kruskal-Wallis) tests and the $P$ values were determined. With respect to the risk of malaria infection in children, all values of $P<0.05$, 95\% confidence interval (CI) for odds ratio (OR) that did not cross 1.00 were considered statistically significant. In the analysis, FcyRIIa-R/H131 polymorphism was used as a reference, due to its utmost prevalence in humans [24]. Using the same software, a $2 \times 2$ chisquare test was used to compare the overall allele frequency. The Hardy-Weinberg equilibrium (HWE) for genotypic deviation was assessed using a chi-squared statistical test. The logistic regression analysis was performed to test for the association between the FcyRs genotypes related to higher levels of anti-malarial IgG subclass among severe malaria compared to uncomplicated malaria patients. Associations were quantified using OR with 95\% CI that did not cross 1.00 with $P$ value $<0.05$, defined as statistically significant. As shown below; each IgG subclass was ranked in malariafree control in two categories based on the levels of anti-malarial antibodies.

\section{Results}

\section{Classification of the study participants}

In this study, demographic data on malaria, parasite density, and disease complication variables were analysed for 600 children of matched gender and age. The 600 subjects were categorised into three different groups. Group I: The malaria-free control [MFC, $\mathrm{n}=200$ (33.3\%) subjects]; included subjects without symptoms of the disease and showed negative results for blood film examination and PCR of the malaria parasites. Group II: Uncomplicated malaria [UM, $\mathrm{n}=218(36.3 \%)$ patients]. Group III: severe malaria [SM, $\mathrm{n}=182(30.3 \%)$ patients]. Group III included patients with severe malaria $[\mathrm{n}=182(30.3 \%)]$, (Table 1). The mean number of parasites in severe malaria patients was significantly higher compared to uncomplicated malaria, $\mathrm{P}<0.001$ (Table 1 ). The body temperature was significantly different between the study populations, $\mathrm{P}<0.001$ (Table 1). 
Table 1 Description of study participants

\begin{tabular}{|c|c|c|c|c|}
\hline Characteristics & $\begin{array}{l}\text { Malaria-Free controls (MFC) } \\
n=200\end{array}$ & $\begin{array}{l}\text { Uncomplicated malaria (UM) } \\
n=218\end{array}$ & $\begin{array}{l}\text { Severe malaria (SM) } \\
n=182\end{array}$ & $\begin{array}{l}\text { P value } \\
\text { Between } \\
\text { Groups }\end{array}$ \\
\hline \multicolumn{5}{|l|}{ Gender } \\
\hline Girls n=321 & $104(52 \%)$ & $115(52.8 \%)$ & $102(56 \%)$ & \multirow[t]{2}{*}{0.704} \\
\hline Boys $n=279$ & $96(48 \%)$ & $103(47.2 \%)$ & $80(44 \%)$ & \\
\hline Age $($ mean $\pm S D)$ & $4.0 \pm 1.4$ & $4.1 \pm 1.4$ & $4.1 \pm 1.1$ & 0.89 \\
\hline Parasite density (mean \pm SD) & NA & $6438.4 \pm 990$ & $15,911.4 \pm 403$ & $<0.001$ \\
\hline Temperature (mean $\pm S D$ ) & $36.9 \pm 0.28$ & $38.9 \pm 0.72$ & $41.1 \pm 0.7$ & $<0.001$ \\
\hline \multicolumn{5}{|l|}{ Malaria complication } \\
\hline Severe anaemia n (\%) & NA & NA & $56(30.8 \%)$ & \multirow[t]{3}{*}{$<0.001$} \\
\hline Cerebral malaria n (\%) & NA & NA & $61(33.5 \%)$ & \\
\hline Other complication ${ }^{\mathrm{a}} \mathrm{n}(\%)$ & NA & NA & $65(35.7 \%)$ & \\
\hline
\end{tabular}

${ }^{a}$ Other complication (hypoglycaemia, jaundice, pulmonary oedema and acute respiratory distress)

\section{Comparison between the distribution of the FcyRIIa genotype and its allelic frequencies among the different study groups}

The genotype frequencies for FcyRIIa did not deviate from the expectations of the HWE in each genotype group (Table 2). The frequencies for the individuals carrying the $F c \gamma R I I a-R / R 131$ genotypes in UM group were lower than the ones in MFC. However, the logistic regression analysis revealed that there was no statistically significant difference between UM and MFC amongst both genotypes $R / R 131$ [ $18.0 \%$ in UM versus $15.1 \%$ in MFC; $\mathrm{OR}=1.39,95 \% \mathrm{CI}(0.89$ to 2.19$)$ and $P$ value $=0.15$ ] (Table 3). In contrast, the genotypes FcyRIIa-H/H131 were statistically significantly higher in UM compared to MFC groups [36.7\% in UM versus 30\% MFC; OR $=0.92$, 95\% CI (0.62 to 1.36$)$ and $P$ value $=0.026]$ using the heterozygotes as the reference group (Table 3 ). The Fc $\gamma$ RIIa-R/R131 genotype was statistically significant associated with SM compared to UM [34.6\% in SM versus $15.1 \%$ in $\mathrm{UM}$; OR $=2.132,95 \% \mathrm{CI}(1.287$ to 3.533$)$ and $P$ value $=0.003]$. In contrast, the $F c \gamma R I I a-H / H 131$ genotype was negatively associated with SM compared to $\mathrm{UM}[13.7 \%$ in $\mathrm{SM}$ versus $36.7 \%$ in $\mathrm{UM}$; OR $=0.349,95 \%$ CI (0.206 to 0.592$)$ and $P$ value $<0.001]$ (Table 3$)$. The frequencies of the FcyRIIa-H/R131 genotype were almost the same among the three groups of MFC, UM, and SM (52.0\%, 48.2\%, and 51.6\%, respectively) (Table 2 ).

\section{Comparison between the distribution of FcyRIIla genotype and its allelic frequencies among the different study groups}

The genotype frequencies showed no statistically significant difference among the FcyRIIIa-F/F in UM compared to MFC (Table 2). The logistic regression

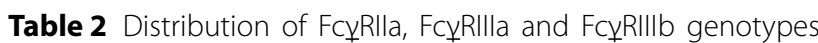
and alleles frequency in the different study groups

\begin{tabular}{|c|c|c|c|}
\hline Genotypes & $\begin{array}{l}\text { Malaria-free } \\
\text { controls } \\
(n=200)\end{array}$ & $\begin{array}{l}\text { Uncomplicated } \\
\text { malaria }(n=218)\end{array}$ & $\begin{array}{l}\text { Severe } \\
\text { malaria } \\
(n=182)\end{array}$ \\
\hline \multicolumn{4}{|l|}{ FcyRlla } \\
\hline $\mathrm{R} / \mathrm{R}(\%)$ & $36(18.0 \%)$ & $33(15.1 \%)$ & $63(34.6 \%)$ \\
\hline$H / R(\%)$ & 104 (52.0\%) & 105 (48.2\%) & $94(51.6 \%)$ \\
\hline$H / H(\%)$ & $60(30.0 \%)$ & $80(36.7 \%)$ & $25(13.7 \%)$ \\
\hline \multicolumn{4}{|c|}{ Allele frequency } \\
\hline R allele & 0.44 & 0.40 & 0.61 \\
\hline Hallele & 0.56 & 0.60 & 0.39 \\
\hline$H W E^{a}$ & 0.44 & 0.87 & 0.28 \\
\hline \multicolumn{4}{|l|}{ FcyRIIIa } \\
\hline$F / F(\%)$ & $91(45.5 \%)$ & 85 (39.0\%) & $132(72.5 \%)$ \\
\hline FN (\%) & 80 (40.0\%) & 105 (48.2\%) & $43(23.6 \%)$ \\
\hline VN (\%) & $29(14.5 \%)$ & $28(12.8 \%)$ & $7(3.8 \%)$ \\
\hline \multicolumn{4}{|c|}{ Allele frequency } \\
\hline F allele & 0.65 & 0.63 & 0.84 \\
\hline Vallele & 0.35 & 0.37 & 0.16 \\
\hline$H W E^{a}$ & 0.10 & 0.62 & 0.15 \\
\hline \multicolumn{4}{|l|}{ FcyRIIIb } \\
\hline NA1/NA1 (\%) & 34 (17.0\%) & $33(15.1 \%)$ & $18(9.9 \%)$ \\
\hline NA1/NA2 (\%) & $92(46.0 \%)$ & 105 (48.2\%) & $70(38.5 \%)$ \\
\hline NA2/NA2 (\%) & 74 (37.0\%) & 80 (36.7\%) & $94(51.6 \%)$ \\
\hline \multicolumn{4}{|c|}{ Allele frequency } \\
\hline NA1 allele & 0.6 & 0.39 & 0.29 \\
\hline NA2 allele & 0.4 & 0.61 & 0.71 \\
\hline$H W E^{\mathrm{a}}$ & 0.56 & 0.88 & 0.36 \\
\hline
\end{tabular}

${ }^{\mathrm{a}}$ If $<0.05$-not consistent with Hardy-Weinberg equilibrium " $H W E^{\prime}$

analysis confirmed the absence of significant differences between UM and MFC among the individuals carrying the $F c \gamma R I I I a-F / F$ genotypes [39\% in UM versus 
Table 3 Association between individual FcyRlla, FcyRIIla and FcyRIIIb genotypes and severity of malaria

\begin{tabular}{|c|c|c|c|c|}
\hline & \multicolumn{2}{|l|}{ UM versus MFC } & \multicolumn{2}{|l|}{ SM versus UM } \\
\hline & Adjusted $^{\mathrm{a}}$ OR $(95 \% \mathrm{CI})$ & $P$ value & Adjusted $^{\mathrm{b}}$ OR (95\% Cl) & $P$ value \\
\hline \multicolumn{5}{|l|}{ FcyRlla } \\
\hline $\mathrm{R} / \mathrm{R}$ & $1.39(0.89-2.19)$ & 0.15 & $2.132(1.287-3.533)$ & 0.003 \\
\hline$H / R$ & 1.00 & & 1.00 & \\
\hline $\mathrm{H} / \mathrm{H}$ & $0.92(0.62-1.36)$ & 0.026 & $0.349(0.206-0.592)$ & $<0.001$ \\
\hline \multicolumn{5}{|l|}{ FcyRIIla } \\
\hline$F / F$ & $1.95(0.65-2.38)$ & 0.79 & $11.51(6.71-19.77)$ & $<0.001$ \\
\hline $\mathrm{F} N$ & 1.00 & & 1.00 & \\
\hline VN & $1.72(1.04-2.82)$ & 0.13 & $0.20(0.09-0.47)$ & $<0.001$ \\
\hline \multicolumn{5}{|l|}{ FcyRIIIb } \\
\hline NA1/NA1 & $0.79(0.48-1.30)$ & 0.354 & $0.82(0.43-1.57)$ & 0.545 \\
\hline NA1/NA2 & 1.00 & & 1.00 & \\
\hline $\mathrm{NA} 2 / \mathrm{NA} 2$ & $1.24(0.85-1.79)$ & 0.263 & $1.76(1.15-2.70)$ & 0.009 \\
\hline
\end{tabular}

adds Ratio (OR) adjusted with sex and age

${ }^{\mathrm{b}}$ Odds Ratio (OR) adjusted with sex, age and Parasite density

$45.5 \%$ in MFC; OR $=1.95,95 \%$ CI $(0.65$ to 2.38$)$ and $P$ value $=0.79]$. Similarly, FcyRIIIa-V $/ V$ genotype showed no statistically significant association with UM compared to MFC $[12.8 \%$ in UM versus $14.5 \%$ in $\mathrm{MFC}$; $\mathrm{OR}=1.72$, 95\% CI (1.04 to 2.82$)$ and $P$ value $=0.13$ ] using the heterozygotes as a reference group (Tables 2 and 3). On the other hand, FcyRIIIa-F/F genotype was statistically associated with SM compared to UM [72.5\% in SM versus $39 \%$ in $\mathrm{UM} ; \mathrm{OR}=11.51,95 \% \mathrm{CI}$ (6.71 to 19.77$)$ and $P$ value $<0.001$ ] (Tables 2 and 3). In contrast, the FcyRIIIa$V / V$ genotype was statistically negatively associated with SM compared to UM [3.8\% in SM versus $12.8 \%$ in UM; $\mathrm{OR}=0.20,95 \% \mathrm{CI}(0.09$ to 0.47$)$ and $P$ value $<0.001$ ] (Tables 2 and 3). The frequency analyses also showed differences in the distributions of the heterozygote FcyRIIIa-F/V genotype among the three groups (40\% in MFC, $48.2 \%$ in UM, and $23.6 \%$ in SM) (Table 2).

The genotype analyses showed similar frequencies between UM and MFC for carrying the FcrRIIIb-NA1/ NA1 genotypes (Table 2). This was confirmed by logistic regression analysis that revealed the lack of statistically significant difference between these two groups in the FcrRIIIb-NA1/NA1 [15\% in UM versus $17.0 \%$ in MFC; OR $=0.79,95 \% \mathrm{CI}(0.48-1.30)$ and $P$ value $=0.354]$ (Tables 2 and 3). Furthermore, NA2/NA2 genotype was not statistically significantly different among UM patients compared to MFC [36.7\% in UM versus $37.0 \%$ in MFC; $\mathrm{OR}=1.24,95 \% \mathrm{CI}(0.85-1.79)$ and $P$ value $=0.263]$ using the heterozygotes as a reference group (Tables 2 and 3). Similarly, there was no statistical difference between patients with SM and UM for FcyRIIIb-NA1/ NA1 genotype [9.9\% in SM versus $15.1 \% \mathrm{UM}$; OR $=0.82$, 95\% CI (0.43 to 1.57$)$ and $P$ value $=0.545$ ] (Tables 2 and
3). However, patients carrying the FcyRIIIb-NA2/NA2 genotype were statistically significantly associated with SM compared to UM [51.6\% in SM versus $36.7 \%$ in $\mathrm{UM} ; \mathrm{OR}=1.76,95 \% \mathrm{CI}(1.15-2.70)$ and $P$ value $=0.009$ ] (Table 2 and 3). The frequency analyses showed differences in the distributions of the heterozygote FcyRIIIa-NA1/NA2 genotype among the three groups (46\% in MFC, $48.2 \%$ in UM, and $38.5 \%$ in SM) (Table 2).

\section{Specific IgG subclass reactivity in the different study groups}

The antibody response for the $P$. falciparum blood-stage antigen AMA-1 was analysed within the different study groups. The current results showed statistically significant differences among the anti-malarial IgG subclass antibody levels in the different study groups; the overall $P$ value $<0.001$ (Table 4). In general, the median value of IgG1 and IgG3 subclass were expressed at higher levels than IgG2 and IgG4 antibodies in the UM group when compared to SM subjects (Table 4). To investigate the potential association between the anti-malarial IgG subclass response and protection against infections; the authors first used a logistic regression model to compare the levels of IgG subclasses between the UM infection and MFC (Table 5). The results showed that a higher level of IgG1 against the AMA-1 antigen was associated with UM patients compared to MFC subjects [OR $=1.04$; 95\% CI (1.01 to 1.07$)$ and $P$ value $=0.012$ ]. In addition, the levels of AMA-1-specific IgG3 were significantly higher in UM patients compared MFC [OR $=1.70$; $95 \%$ CI (1.47 to 1.95$)$ and $P$ value $<0.001]$ (Table 5). There was no observed association for the AMA-1-specific IgG2 and IgG4 responses in UM compared to MFC (Table 5). 
Table 4 Comparison of Anti-AMA1 lgG subclasses $(\mu \mathrm{g} / \mathrm{mL})$ among different study groups

\begin{tabular}{lllll}
\hline Group & $\begin{array}{l}\text { IgG1 } \\
\text { Median (Q1-Q3) }\end{array}$ & $\begin{array}{l}\text { IgG2 } \\
\text { Median (Q1-Q3) }\end{array}$ & $\begin{array}{l}\text { IgG3 } \\
\text { Median (Q1-Q3) }\end{array}$ & $\begin{array}{l}\text { IgG4 } \\
\text { Median (Q1-Q3) }\end{array}$ \\
\hline Malaria-free controls $(\mathrm{n}=200)$ & $3.91(0.2-35.6)$ & $0.89(0.1-15.1)$ & $1.1(0.02-15.4)$ & $0.4(0.1-1.7)$ \\
Uncomplicated malaria $(\mathrm{n}=218)$ & $4.23(0.3-47)$ & $0.73(0.1-43.6)$ & $3.6(1-29.6)$ & $0.3(0.1-3.9)$ \\
Severe malaria $(\mathrm{n} 182)$ & $2.97(0.3-25.7)$ & $3.35(0.3-45.3)$ & $2(1-8.5)$ & $1.2(0.2-14.2)$ \\
P value* & $<0.001$ & $<0.001$ & $<0.001$ & $<0.001$ \\
\hline
\end{tabular}

AMA-1 Apical membrane antigen 1

* $\mathrm{P}$ value was derived from Kruskal-wallis between the study groups

Table 5 Logistic regression analysis of malaria specific (anti-AMA1) lgG subclasses levels among the different study groups

\begin{tabular}{|c|c|c|c|c|}
\hline \multirow{2}{*}{$\begin{array}{l}\text { Dependent Variable } \\
\operatorname{lgG1} A M A 1\end{array}$} & \multicolumn{2}{|c|}{ Model of independent variables } & \multirow{2}{*}{\begin{tabular}{|l} 
OR $(95 \% \mathrm{Cl})$ \\
$1.04(1.01$ to 1.07$)$
\end{tabular}} & \multirow{2}{*}{$\begin{array}{r}\text { P value } \\
0.012\end{array}$} \\
\hline & Uncomplicated malaria & $\mathrm{MFC}^{\mathrm{a}}$ & & \\
\hline & & $S M^{b}$ & 0.89 (0.84 to 0.94$)$ & $<0.001$ \\
\hline \multirow[t]{2}{*}{$\lg G 2 \mathrm{AMA} 1$} & Uncomplicated malaria & MFC & 1.02 (0.95 to 1.08$)$ & 0.640 \\
\hline & & SM & 1.41 (1.27 to 1.57$)$ & $<0.001$ \\
\hline \multirow[t]{2}{*}{$\operatorname{lgG} 3$ AMA1 } & Uncomplicated malaria & MFC & $1.70(1.47$ to 1.95$)$ & $<0.001$ \\
\hline & & SM & 0.52 (0.43 to 0.62 ) & $<0.001$ \\
\hline \multirow[t]{2}{*}{$\operatorname{lgG} 4 \mathrm{AMA} 1$} & Uncomplicated malaria & MFC & 1.08 (0.65 to 1.79$)$ & 0.77 \\
\hline & & SM & 15.57 (8.3 to 29.20$)$ & $<0.001$ \\
\hline
\end{tabular}

a OR represent odds ratios while $\mathrm{Cl}$ represents confidence intervals. In model (A) uncomplicated versus malaria-free control "MFC": malaria-free controls were assigned 0 uncomplicated malaria patients were assigned 1 in the logistic regression analysis. OR above 1 represented value higher levels antimalarial lgG subclass associated to uncomplicated malaria while less than 1 value represented malaria-free controls

${ }^{b}$ In model (B) severe malaria versus uncomplicated malaria: uncomplicated malaria was assigned 0 severe malaria patients were assigned 1 in the logistic regression analysis. OR above 1 represented value higher levels antimalarial IgG subclass associated to severe malaria while less than 1 value represented uncomplicated malaria

The second logistic regression model confirmed that the apparent anti-malarial IgG2 and IgG4 antibodies were statistically significantly higher in SM patients when compared to UM patients (Table 5). However, the levels of AMA-1-specific IgG1 and IgG3 were significantly lower in SM group compared to UM patients [for IgG1: $\mathrm{OR}=0.89 ; 95 \% \mathrm{CI}(0.84$ to 0.94$)$ and $P$ value $<0.001$ and for IgG3: $\mathrm{OR}=0.52 ; 95 \% \mathrm{CI}(0.43$ to 0.62$)$ and $P$ value $<0.001$ )] (Table 5).

The results indicated that patients carrying the FcyRIIa-H/H131 genotype are significantly associated with higher expression levels of the anti-malarial IgG1, IgG2 and IgG4 antibodies, but not IgG3 in UM patients [for IgG1: $\mathrm{OR}=0.3 ; 95 \% \mathrm{CI}(0.2$ to 0.6$)$ and $P$ value $<0.001$, for IgG2: $\mathrm{OR}=0.5 ; 95 \% \mathrm{CI}(0.3$ to 0.8$)$ and $P$ value $=0.006$ and for IgG4: $\mathrm{OR}=0.5 ; 95 \% \mathrm{CI}$ (0.3 to 0.8 ) and $P$ value $=0.006$ ] (Table 6). Comparatively, patients harbouring the FcyRIIa-R/R131 genotype show significantly increased levels of anti-malarial IgG2 antibodies and associated with SM compared to UM [OR $=3.7 ; 95 \%$ CI $(2.0$ to 6.7$)$ and $P$ value $<0.001$ ] (Table 6). However, patients carrying the genotype FcyRIIa-R/R131 are statistically negatively associated with higher levels of AMA-1-specific IgG3 $[\mathrm{OR}=0.4$; 95\% CI $(0.2$ to 0.6$)$ and $\mathrm{P}$ value<0.001] (Table 6).
Independently, the model of the multivariate logistic regression analysis of individuals carrying the Fc $\gamma$ RIIIa$F / F$ genotype is significantly associated with higher levels of AMA-1-specific IgG2 and IgG4 antibodies in SM compared to UM patients [for IgG2: $\mathrm{OR}=3.9 ; 95 \% \mathrm{CI}$ (2.4 to 6.4) and $P$ value $<0.001$ and for IgG4: $\mathrm{OR}=3.2$; 95\% CI (2.1 to 5.3) and $P$ value $<0.001$ ] (Table 6). These results together clearly show that the FcyRIIIa-F/F genotype is negatively associated with higher expression levels of AMA-1-specific IgG3 among SM compared to UM patients $[\mathrm{OR}=0.2 ; 95 \% \mathrm{CI}(0.1$ to 0.4$)$ and $P$ value $<0.001$ ] (Table 6). Similarly, our data show that the $F c \gamma R I I I a-V / V$ genotype is negatively associated with higher levels of AMA-1-specific IgG4 in SM compared to UM subjects [OR $=0.4 ; 95 \% \mathrm{CI}(0.2$ to 0.6$)$ and $P$ value $<0.001$ ] (Table 6).

Furthermore, the analyses of the results show that the FcyRIIIb-NA2/NA2 genotype is significantly associated with a higher level of AMA-1-specific IgG4 among SM compared to UM group [OR $=1.7 ; 95 \% \mathrm{CI}$ (1.1 to 2.7$)$ and $P$ value $=0.011]$ (Table 6). The current results indicate that the $F c \gamma R I I I b$ genotypes are not associated with the independent action of the three IgG subclasses (IgG1, IgG2, and IgG3) of antibodies, and maybe due to the absence of interaction in the logistic regression model. 
Table 6 Logistic regression analysis of individual carrying FcyRIla, FcyRIIla, FcyRIllb genotypes in relation of the levels specific IgG subclasses associated with uncomplicated compared to severe malaria

\begin{tabular}{|c|c|c|c|c|}
\hline FcyRs genotype s & $\begin{array}{l}\text { Antimalrial IgG-AMA-1 } \\
\text { subclasses }\end{array}$ & Genotypes & Adjusted OR ${ }^{a}(95 \% \mathrm{Cl})$ & $P$ value \\
\hline \multirow[t]{12}{*}{ FcgRlla } & $\lg G 1$ & $\mathrm{R} / \mathrm{R} 131$ & $2.3(1.4-3.4)$ & 0.485 \\
\hline & & $\mathrm{H} / \mathrm{R} 131$ & 1 & \\
\hline & & H/H131 & $0.3(0.2-0.6)$ & $<0.001$ \\
\hline & $\lg G 2$ & $\mathrm{R} / \mathrm{R} 131$ & $3.7(2.0-6.7)$ & $<0.001$ \\
\hline & & H/R131 & 1 & \\
\hline & & $\mathrm{H} / \mathrm{H} 131$ & $0.5(0.3-0.8)$ & 0.006 \\
\hline & $\lg G 3$ & R/R131 & $0.4(0.2-0.6)$ & $<0.001$ \\
\hline & & $\mathrm{H} / \mathrm{R} 131$ & 1 & \\
\hline & & H/H131 & $1.4(0.8-2.3)$ & 0.28 \\
\hline & $\lg G 4$ & $\mathrm{R} / \mathrm{R} 131$ & $3.2(1.8-5.7)$ & $<0.001$ \\
\hline & & H/R131 & 1 & \\
\hline & & H/H131 & $0.5(0.3-0.8)$ & 0.006 \\
\hline \multirow[t]{12}{*}{ FcyRIIla } & $\lg G 1$ & $F / F$ & $0.8(0.5-1.2)$ & 0.272 \\
\hline & & FN & 1 & \\
\hline & & VN & $1.3(0.8-2.2)$ & 0.326 \\
\hline & $\lg G 2$ & $F / F$ & $3.9(2.4-6.4)$ & $<0.001$ \\
\hline & & FN & 1 & \\
\hline & & VN & $0.4(0.3-0.7)$ & 0.002 \\
\hline & $\lg G 3$ & $F / F$ & $0.2(0.1-0.4)$ & $<0.001$ \\
\hline & & FN & 1 & \\
\hline & & VN & $1.8(0.9-3.7)$ & 0.096 \\
\hline & $\operatorname{lgG} 4$ & $F / F$ & $3.2(2.1-5.3)$ & $<0.001$ \\
\hline & & FN & 1 & \\
\hline & & VN & $0.4(2.0-0.6)$ & $<0.001$ \\
\hline \multirow[t]{12}{*}{ FcyRIIIb } & $\operatorname{lgG} 1$ & NA1/NA1 & $1.3(0.7-2.4)$ & 0.47 \\
\hline & & NA1/NA2 & 1 & \\
\hline & & $\mathrm{NA} 2 / \mathrm{NA} 2$ & $0.9(0.6-1.4)$ & 0.71 \\
\hline & $\lg G 2$ & $\mathrm{NA1} / \mathrm{NA} 1$ & $1.0(0.6-1.9)$ & 0.94 \\
\hline & & NA1/NA2 & 1 & \\
\hline & & NA2/NA2 & $1.4(0.9-2.1)$ & 0.14 \\
\hline & $\lg G 3$ & NA1/NA1 & $0.9(0.5-1.7)$ & 0.72 \\
\hline & & $\mathrm{NA1} / \mathrm{NA} 2$ & 1 & \\
\hline & & NA2/NA2 & $0.9(0.6-1.4)$ & 0.71 \\
\hline & $\lg G 4$ & $\mathrm{NA1} / \mathrm{NA} 1$ & $1.2(0.6-2.2)$ & 0.61 \\
\hline & & NA1/NA2 & 1 & \\
\hline & & NA2/NA2 & $1.7(1.1-2.7)$ & 0.011 \\
\hline
\end{tabular}

${ }^{a}$ OR represent odds ratios while Cl represents confidence intervals. "OR" adjusted with parasite density. Higher levels of antimalarial lgG subclasses among uncomplicated malaria patients were assigned 0 while higher levels antimalarial IgG subclasses among severe malaria patients were assigned 1 in the logistic regression analysis. OR above 1 represented value associated to higher levels antimalarial lgG subclasses among severe malaria patients while less than 1 value represented higher levels antimalarial lgG subclasses among uncomplicated malaria patients

\section{Discussion}

This study aimed to evaluate the possible relationship between the variants of FcyRIIa (CD32a), FcyRIIIa (CD16a), FcyRIIIb (CD16b) gene polymorphism and $P$. falciparum AMA-1-specific IgG subclass and its importance in the susceptibility to complicated malaria infections among children in Saudi Arabia. This study is the country's first report investigating this association among children.

The data of this investigation suggested that there was no significant impact of the FcyRIIa-R/H131 genotypes polymorphism on the susceptibility to UM infection compared to MFC. This finding is in parallel with the previously published report from Eastern Sudan by Giha 
and co-workers, which suggested the lack of statistically significant association between FcyRIIa-R/H131 genotypes polymorphism on immunity and susceptibility to UM infection [25]. This may be due to the similarities in malaria epidemiology, malaria transmission, and patient's semi-immunity to malaria infection $[3,16]$. In contrast, the study of Shi et al. demonstrated a protective effect against UM for FcyRIIa-R/R131 compared with the heterozygote $F c \gamma R I I a-R / H 131$ genotype carriers in infants below one year of age [26]. Therefore, there is no general agreement regarding the role of FcyRIIa-R/H131 in $\mathrm{UM}$ infection. In the present study, the logistic regression model suggests that the genotypes FcyRIIa-R/R131 are statistically significantly associated with increased susceptibility to SM infection (2.1-fold) when compared to UM patients. In contrast, the current data indicates that the FcyRIIa-H/H131 is negatively associated with SM (0.349-fold decrease) compared to UM patients. Similarly, in a former study, the authors have reported that the FcyRIIa-R/R131 genotypes are associated with SM, while the FcyRIIa-H/H131 genotypes show a significant association with mild malaria among Sudanese patients residing in East Sudan [9]. Previously published case-control investigations have demonstrated that Fc $\gamma$ RIIa-R/R131 genotypes are associated with protection against high parasite density [26], and the genotypes of FcyRIIa-H/H131 are correlated with high risk of either severe malaria or placental malaria [27-29]. Interestingly, the current study found that the levels of IgG1, IgG2, and IgG4 are associated with FcyRIIa-H/H131 in the UM patients. Nasr et al. have suggested similar results among the Fulani ethnic group that are less susceptible to severe malaria infection [11]. In contrast, previous data on pregnant women with asymptomatic malarial infection (ASM) revealed that the high levels of AMA-1-specific anti-malarial IgG1, IgG2, and IgG4 antibodies are statistically associated with R/R131 carriers rather than the genotype FcyRIIa-H/H131 [3]. This contradiction may be due to the variation in the individual's genetic background, and variation in study designs.

The results of this study suggest that the relative reduction in malaria infection in the UM group cannot be explained solely by the magnitude and quality of the humoral response to malaria. Additional studies are needed to clarify whether the FcyRIIa-R/H131 polymorphism is a causative factor in the variable predisposition to malaria that is demonstrated among the different groups.

This study also revealed that the FcyRIIIa-F/V176 genotypes are not associated with UM patients compared to MFC. On the other hand, the FcyRIIIa-F/ F176 genotype is statistically associated with SM compared to UM patients. However, patients carrying the
FcyRIIIa-V/V176 genotypes are statistically associated with protection against SM compared to UM. The latter finding is in line with a recent Kenyan study, which shows that the polymorphisms in the FcyRIIIa-V/V are associated with protection against severe malaria and modulations in circulating IFN $\gamma$ levels [12]. In contrast, a previous investigation on Thai patients did not show an association between $F c \gamma R I I I a-F / V 176$ genotypes and the severity of the disease [29]. Again, these discrepancies may be attributed to the difference in ethnicity and study design.

The current study suggests that individuals carrying the $F c \gamma R I I I a-F / F$ genotype are significantly expressing higher levels of AMA-1-specific IgG2 and IgG4 antibodies in the SM group compared to patients with UM. In agreement with this finding, Koene et al. have shown that the $F c \gamma R I I I a-F / F$ is significantly less bound to IgG1, IgG3, and IgG4 compared to the FcyRIIIa-V/V genotypes [30].

The study's results suggest that there are no statistically significant differences between UM and MFC for the FcyRIIIb-NA1/NA1 and FcyRIIIb-NA2/NA2 genotypes. In contrast, the patients carrying the FcyRIIIb-NA2/NA2 genotype are significantly associated with SM compared to patients with UM. Recent work on children living in Western Kenya suggests that the FcyRIIIb-NA1/NA2 gene polymorphisms are not significantly associated with susceptibility to severe malaria [12]. In addition, the study performed by Adu et al. have demonstrates that the FcyRIIIb-NA2/NA2 in Ghanaian children is associated with clinical malaria [4]. In 2010, Adu demonstrated an association between the FcyRIIIb-NA2/NA2 and susceptibility to severe and uncomplicated malaria among Ghanaian children [31]. These contradicting results may be attributed to the different malaria transmission seasons and malaria epidemics. Moreover, different ethnicity associated with variations in the genetic background may significantly contribute to the $F c \gamma R$ gene polymorphism and susceptibility/protection to severe malaria [11].

\section{Strength and limitations}

To the best of the authors knowledge, this is the first study in the Kingdom of Saudi Arabia which highlighted the relation between $F c \gamma R$ genotypes polymorphism, IgG subclass and malaria infection among Saudi children. This will hopefully lead to further research in the area. Some of the studies limitations include the small sample size and the fact that the study was performed in one region of Saudi Arabia instead of it being multicentred. As such findings need to be confirmed in a large sample size from various regions representing the whole endemic area. 


\section{Conclusion}

This study reveals significant influence of the FcyRIIa-R/ R131, FcyRIIIa-F/F176 and the FcyRIIIb-NA2/NA2 genotypes in increasing the susceptibility to severe malaria. Binding between the FcyR genotypes and IgG subclass results in changes in the ability of the immune cells to respond to infection through secretion of inflammatory mediators during $P$. falciparum infection. Further studies are underway in our laboratory to elucidate if the FcyRIIa, FcyRIIIa and FcyRIIIb genotypes polymorphism contribute to the differential susceptibility to malaria among the different study groups.

\begin{abstract}
Abbreviations
AMA-1: Apical membrane antigen 1; AMPSJ: Aledabi Malaria Prevention Station in Jazan; ASRED: Allele specific restriction enzyme digestion; BMGHJ: Bani Malik General Hospital in Jazan; FcyR: Fc-gamma receptors; PCR: Polymerase chain reaction
\end{abstract}

\section{Acknowledgements}

The authors are grateful to the patients, control volunteers and their families. We are also grateful to the staff of the Bani Malik General Hospital and Aledabi Malaria Prevention Station in Jazan region (BMGHJ \& AMPSJ) of Saudi Arabia, for their sustained cooperation and help in sample collection. The authors are grateful to Dr. Hamza A., Dundee University, United Kingdom, for improving the English language and proofreading the manuscript. This research study is financially supported by the grant number (RC13/246) obtained from King Abdullah International Medical Research Centre (KAIMRC), National Guard Health Affairs, Riyadh, Saudi Arabia.

\section{Authors' contributions}

AN, AA and SAM drafted the idea of the research proposal, researched data, and designed the experiments. AN, AA, HO, HAE, ME, AA, ATH, AA, AA and SAM wrote the first draft of the manuscript. AN, AA, HAE, SAM, and AA performed the ELISA and participated in the gene polymorphism analysis. AN and ME conducted the data analysis and contributed to the writing of the statistical components in the study. AN, OH and ATH contributed to patient recruitment, diagnosis management and reviewed the research project protocol. All authors read and approved the final manuscript.

\section{Funding}

This study was financially supported by King Abdullah International Medical Research Centre (KAIMRC), Health Affairs, Ministry of National Guard, Riyadh, Saudi Arabia, (Grant Number: RC13/246).

\section{Availability of data and materials}

The datasets used and/or analysed during the current study are available from the corresponding author upon request.

\section{Declarations}

\section{Ethics approval and consent to participate}

This study was approved by the Institutional Reviewed Board (IRB) of King Abdulaziz Medical City, Health Affairs, Ministry of National Guard, Riyadh, Saudi Arabia. Prior to participation, informed consent was obtained from children and their parents/guardians.

\section{Consent for publication}

Not applicable.

\section{Competing interests}

The authors declare no competing interests.

\section{Author details}

${ }^{1}$ Department of Basic Medical Sciences, College of Medicine, King Saud Bin Abdulaziz University for Health Sciences (KSAU-HS), Riyadh, Kingdom of Saudi Arabia. ${ }^{2}$ Department of Immunology, King Abdullah International Medical Research Centre (KAIMRC), Ministry of National Guard- Health Affairs, Riyadh, Kingdom of Saudi Arabia. ${ }^{3}$ Department of Biochemistry and Molecular Medicine, College of Medicine, Alfaisal University, Riyadh, Saudi Arabia. ${ }^{4}$ Department of Public Health, Jazan Health Affairs- District Ministry of Health, Jazan, Saudi Arabia. ${ }^{5}$ Department of Pharmacology, College of Medicine, Taif University, POBox 888, Taif 21944, Saudi Arabia. ${ }^{6}$ Department of Medical Education, College of Medicine-Riyadh, King Saud Bin Abdul-Aziz University for Health Sciences, (KSAU-HS), Riyadh, Kingdom of Saudi Arabia. ${ }^{7}$ Infectious Disease Division, Department of Medicine, King Abdulaziz Medical City, National Guard Health Affairs, RiyadhRiyadh, Saudi Arabia. ${ }^{8}$ Department of Medicine, College of Medicine, King Saud Bin Abdulaziz University for Health Sciences (KSAU-HS), Riyadh, Kingdom of Saudi Arabia. ${ }^{9}$ Department of Basic Medical Sciences, College of Medicine, King Saud Bin Abdul-Aziz University for Health Sciences, Jeddah, Kingdom of Saudi Arabia. ${ }^{10}$ King Abdullah International Medical Research Centre (KAIMRC), National Guard Health Affairs, Jeddah, Kingdom of Saudi Arabia. ${ }^{11}$ Department of Clinical Laboratory Sciences, College of Applied Medical Sciences, King Saud Bin Abdulaziz University for Health Sciences (KSAU-HS), Jeddah, Kingdom of Saudi Arabia.

Received: 3 February 2021 Accepted: 1 September 2021

Published online: 22 September 2021

\section{References}

1. WHO: World malaria report 2019; 2019. https://appswhoint/iris/bitst ream/handle/10665/330011/9789241565721-eng.pdf.

2. Ravetch JV, Bolland S. IgG Fc receptors. Annu Rev Immunol. 2001;19:275-90.

3. Nasr A, Hamid O, Al-Ghamdi A, Allam G. Anti-malarial lgG subclasses pattern and FcgammaRlla (CD32) polymorphism among pregnancyassociated malaria in semi-immune Saudi women. Malar J. 2013;12:110.

4. Adu B, Dodoo D, Adukpo S, Hedley PL, Arthur FK, Gerds TA, et al. Fc gamma receptor IIIB (FcgammaRIIIB) polymorphisms are associated with clinical malaria in Ghanaian children. PLoS one. 2012;7:e46197.

5. van Sorge NM, van der Pol WL, van de Winkel JG. FcgammaR polymorphisms: implications for function, disease susceptibility and immunotherapy. Tissue Antigens. 2003;61:189-202.

6. Ogoe BM, Wilson MD, Yaa OD, Rogers W, Brown CA, Adu D. Studies on the allotypic variants of IgG receptors Fc gamma RIIA and Fc gamma IIlb and their association with severe clinical malaria among Ghanaian children. The Third MIM Pan-African Malaria Conference 2002, Abstract No: 166:116.

7. Omi K, Ohashi J, Patarapotikulb J, Hananantachai H, Naka I, Looareesuwan $\mathrm{S}$, et al. Fcgamma receptor IIA and IIIB polymorphisms are associated with susceptibility to cerebral malaria. Parasitol Int. 2002;51:361-6.

8. Ntoumi F, Flori L, Mayengue PI, Matondo Maya DW, Issifou S, Deloron P, et al. Influence of carriage of hemoglobin AS and the Fc gamma receptor Ila-R131 allele on levels of immunoglobulin G2 antibodies to Plasmodium falciparum merozoite antigens in Gabonese children. J Infect Dis. 2005;192:1975-80.

9. Nasr A, Iriemenam NC, Troye-Blomberg M, Giha HA, Balogun HA, Osman OF, et al. Fc gamma receptor Ila (CD32) polymorphism and antibody responses to asexual blood-stage antigens of Plasmodium falciparum malaria in Sudanese patients. Scand J Immunol. 2007;66:87-96.

10. Nasr A, Elghazali G, Giha H, Troye-Blomberg M, Berzins K. Interethnic differences in carriage of haemoglobin AS and Fcgamma receptor Ila (CD32) genotypes in children living in eastern Sudan. Acta Trop. 2008;105:191-5.

11. Nasr A, Iriemenam NC, Giha HA, Balogun HA, Anders RF, Troye-Blomberg $\mathrm{M}$, et al. FcgammaRlla (CD32) polymorphism and anti-malarial IgG subclass pattern among Fulani and sympatric ethnic groups living in eastern Sudan. Malar J. 2009;8:43.

12. Munde EO, Okeyo WA, Raballah E, Anyona SB, Were T, Ong'echa JM, et al. Association between Fcgamma receptor IIA, IIIA and IIIB genetic polymorphisms and susceptibility to severe malaria anemia in children in western Kenya. BMC Infect Dis. 2017;17:289. 
13. Amiah MA, Ouattara A, Okou DT, N'Guetta SPA, Yavo W. Polymorphisms in Fc gamma receptors and susceptibility to malaria in an endemic population. Front Immunol. 2020;11:561142.

14. Al-Tawfiq JA. Epidemiology of travel-related malaria in a non-malarious area in Saudi Arabia. Saudi Med J. 2006;27:86-9.

15. Malik GM, Seidi O, El-Taher A, Mohammed AS. Clinical aspects of malaria in the Asir Region, Saudi Arabia. Ann Saudi Med. 1998:18:15-7.

16. Nasr A, Allam G, Hamid O, Al-Ghamdi A. IFN-gamma and TNF associated with severe falciparum malaria infection in Saudi pregnant women. Malar J. 2014;13:314.

17. WHO. World malaria report 2019. Geneva: World Health Organization; 2019.

18. Nasr A, Abushouk A, Hamza A, Siddig E, Fahal AH. Th-1, Th-2 cytokines profile among Madurella mycetomatis eumycetoma patients. PLoS Negl Trop Dis. 2016;10:e0004862.

19. Snijdewind IJ, van Kampen JJ, Fraaij PL, van der Ende ME, Osterhaus AD, Gruters RA. Current and future applications of dried blood spots in viral disease management. Antiviral Res. 2012;93:309-21.

20. Coley AM, Gupta A, Murphy VJ, Bai T, Kim H, Anders RF, et al. Structure of the malaria antigen AMA1 in complex with a growth-inhibitory antibody. PLoS Pathog. 2007;3:e138.

21. Iriemenam NC, Khirelsied AH, Nasr A, ElGhazali G, Giha HA, Elhassan AETM, et al. Antibody responses to a panel of Plasmodium falciparum malaria blood-stage antigens in relation to clinical disease outcome in Sudan. Vaccine. 2009;27:62-71.

22. Nasr A, Saleh AM, Eltoum M, Abushouk A, Hamza A, Aljada A, et al. Antibody responses to $P$. falciparum Apical Membrane Antigen 1 (AMA-1) in relation to haemoglobin S (HbS), HbC, G6PD and ABO blood groups among Fulani and Masaleit living in Western Sudan. Acta Trop. 2018;182:115-23.

23. Bux J, Stein EL, Santoso S, Mueller-Eckhardt C. NA gene frequencies in the German population, determined by polymerase chain reaction with sequence-specific primers. Transfusion. 1995;35:54-7.

24. Rascu A, Repp R, Westerdaal NA, Kalden JR, van de Winkel JG. Clinical relevance of Fc gamma receptor polymorphisms. Ann NY Acad Sci. 1997;815:282-95
25. Giha HA, Nasr A, Iriemenam NC, Troye-Blomberg M, Berzins K, ElGhazali G. Lack of significant influence for FcgammaRlla-RH131 or hemoglobin AA/AS polymorphisms on immunity and susceptibility to uncomplicated malaria and existence of marked linkage between the two polymorphisms in Daraweesh. Microbes Infect. 2012;14:537-44.

26. Shi YP, Nahlen BL, Kariuki S, Urdahl KB, McElroy PD, Roberts JM, et al. Fcgamma receptor lla (CD32) polymorphism is associated with protection of infants against high-density Plasmodium falciparum infection. VII. Asembo Bay Cohort Project. J Infect Dis. 2001;184:107-11.

27. Brouwer KC, Lal AA, Mirel LB, Otieno J, Ayisi J, Van Eijk AM, et al. Polymorphism of Fc receptor Ila for immunoglobulin $G$ is associated with placental malaria in HIV-1-positive women in western Kenya. J Infect Dis. 2004;190:1192-8.

28. Cooke GS, Aucan C, Walley AJ, Segal S, Greenwood BM, Kwiatkowski DP, et al. Association of Fcgamma receptor lla (CD32) polymorphism with severe malaria in West Africa. Am J Trop Med Hyg. 2003;69:565-8.

29. Omi K, Ohashi J, Patarapotikul J, Hananantachai H, Naka I, Looareesuwan S, et al. Fc gamma receptor IIA and IIIB polymorphisms are associated with susceptibility to cerebral malaria. Parasitol Int. 2002;51:361-6.

30. Koene HR, Kleijer M, Algra J, Roos D, von dem Borne AE, de Haas M. FC gammaRIIla-158V/F polymorphism influences the binding of IgG by natural killer cell Fc gammaRIIla, independently of the Fc gammaRIIla48L/R/H phenotype. Blood. 1997;90:1109-14.

31. Adu B. Immunological and Genetic Correlates of Immunity to Plasmodium falciparum Malaria. A (MPhil) Thesis Submitted to the Department of Biochemistry and Biotechnology, Kwame Nkrumah University of Science and Technology, Kumasi; 2010, http://ir.knust.edu.gh/handle/12345 $6789 / 481$

\section{Publisher's Note}

Springer Nature remains neutral with regard to jurisdictional claims in published maps and institutional affiliations.
Ready to submit your research? Choose BMC and benefit from:

- fast, convenient online submission

- thorough peer review by experienced researchers in your field

- rapid publication on acceptance

- support for research data, including large and complex data types

- gold Open Access which fosters wider collaboration and increased citations

- maximum visibility for your research: over 100M website views per year

At BMC, research is always in progress.

Learn more biomedcentral.com/submissions 